\title{
CEO Presence on the Compensation Committee: A Puzzle*
}

\author{
Glenn Boyle ${ }^{\dagger}$ \\ Department of Economics and Finance \\ University of Canterbury \\ Helen Roberts \\ Department of Accountancy and Finance \\ University of Otago
}

January 31, 2012

*For helpful comments on earlier versions of this paper, we are grateful to Henk Berkman, Rick Boebel, Stu Gillan, seminar attendees at Otago University, and session participants at the 2009 New Zealand Finance Colloquium and the 2010 Finance and Corporate Governance Conference (Melbourne). Thanks also to Richa Jain for valuable research assistance, to the Targeted Research Development Assistance programme at the University of Otago for funding part of the data collection, and to the New Zealand Institute for the Study of Competition and Regulation for additional financial support. Any remaining errors or ambiguities are solely our responsibility.

${ }^{\dagger}$ Corresponding author: Private Bag 4800, Christchurch 8140, New Zealand. Phone: 64-3-364-3479; Fax 64-3-364-2635. Email: glenn.boyle@canterbury.ac.nz 


\title{
CEO Presence on the Compensation Committee: A Puzzle
}

\begin{abstract}
Conventional wisdom suggests that CEO membership of the compensation committee is an open invitation to rent extraction by self-serving executives. However, using data from New Zealand - where CEO compensation committee membership is relatively common - we find that annual pay increments for CEOs with this apparent advantage averaged six percentage points less than those enjoyed by other CEOs during the 1997-2005 period. After controlling for variation in firm performance, the difference is a still-sizeable four percentage points. This puzzling result cannot be explained by risk-return tradeoff considerations, interaction with other governance variables, selection bias, or variable mis-measurement.
\end{abstract}

JEL classification: G34, J33

Keywords: compensation committee; CEO remuneration 


\section{CEO Presence on the Compensation Committee: A Puzzle}

\section{Introduction}

Chief Executive Officer (CEO) membership of the firm's compensation committee would seem to provide an ideal setting for opportunistic CEO behaviour. Even when such CEOs are excluded from discussions relating to their own remuneration, committee membership can still be advantageous: for example, by the negotiation of favorable pay structures and packages for their subordinate executives - which then need to be passed on to CEOs in order to maintain 'relativity'. At the other end of the spectrum, CEOs who are not part of the board of directors would appear to be in a relatively weak bargaining position when it comes to negotiating their personal remuneration. In this paper, we ask whether such extremes of CEO 'influence' on the pay-setting process are reflected in remuneration outcomes. We find that they are, but not in the way intuition would suggest.

Precisely because of the bargaining-power imbalances they potentially create, situations where the $\mathrm{CEO}$ sits on the compensation committee, or is off the board altogether, are extremely rare, at least in the United States (US). For example, Anderson and Bizjak (2003), Klein (1998), Newman and Mozes (1999) and Vafeas (2003) all report a general absence of CEOs from US firm compensation committees, while LeBlanc and Gillies (2005, p92) claim that: "(i)t is almost unheard of for the chief executive officer of the corporation not to be a member of the board of directors."

Such homogeneity does not exist everywhere, however. One country where much greater variation in CEO involvement occurs is New Zealand (NZ): in a sample of NZ listed firms during the 1997-2005 period, approximately 1/3 appoint their CEO to the compensation committee, while slightly fewer than 1/4 of CEOs are excluded from the board altogether.

We find that this variation in CEO pay-setting involvement has an unexpected outcome: after controlling for firm performance, CEO membership of the compensation committee is associated with an approximately four percentage point reduction in average annual pay growth. That is, CEOs with the most direct involvement in the setting of their own remuneration are, on average, rewarded less generously than those who are kept at arms-length. This puzzling result cannot be explained by mis-measurement of CEO remuneration or board involvement, or a risk-return tradeoff by risk-averse CEOs, or omitted governance variables, or selection considerations. Overall, these results present a challenge to conventional wisdom about the link between governance structures and CEO remuneration.

In the next section, we describe our data sources and properties. Section 3 contains our results linking CEO pay outcomes to participation in the pay-setting process, 
while section 4 considers the impact of such participation on subsequent firm performance. Finally, section 5 offers some concluding remarks.

\section{Data}

Our initial sample consists of companies listed on the NZ Stock Exchange (NZX) between 1997 and 2005. We begin in 1997 because NZ firms were not required to disclose executive compensation details prior to that time. ${ }^{1}$ Compensation and governance information come from a hand-collected dataset obtained from company annual reports. Older reports were obtained from the now-defunct Commerce Resource Library at Otago University; more recent report information comes from the NZX Company Research database. Stock return data, including adjustment factors, were sourced from the Otago University Sharemarket Database, with supplementation from NZX. In each year, firms were excluded from the sample if (i) there was missing information, (ii) they were only listed on the secondary board, (iii) they delisted during the year, or (iv) the CEO was not in office for the entire current and previous year. The final sample consists of 502 firm-year observations for 114 different NZX firms over the nine year period between 1997 and 2005. With 55 such observations in 1997, this leaves 447 'first-difference' observations over the sample period.

We focus on what Newman and Mozes (1999) call 'firm-awarded' compensation, i.e., remuneration that is under the direct control of the firm. This has two components: (i) salary, bonus and allowances, and (ii) new stock and option grants. NZ annual reports directly provide, in a manner to be described below, data on the first component. They also report information on any stock or option grants made during the year, which in principle allows estimation of the second. However, stock and option awards occur infrequently in NZ firms during the sample period (11\% of firm-years) and are of minor value (approximately $6.4 \%$ of the value of component (i) for the firms where we are able to value option grants). Moreover, 36 option grants in our sample (70\% of those issued) are unable to be valued due to insufficient information being reported. Given the low frequency and limited importance of such grants in NZ, we avoid any further reduction in sample size by henceforth confining our attention to component (i). We examine the importance of this restriction in section 4 .

NZ compensation disclosure requires that the sum of salary, bonus, superannuation, health insurance coverage, and motor vehicle allowance be reported in the following ways. For executives who are members of the board of directors, the exact value of this remuneration appears in a separate table of the annual report. For other employees, individual details are not reported, only the number of workers receiving remuneration lying within each $\$ 10,000$ interval over and above $\$ 100,000$ per annum. Consequently, we record compensation for any $\mathrm{CEO}$ not on the board of directors as being equal to the midpoint of

\footnotetext{
${ }^{1}$ See Andjelkovic et al.(2002) for details of the legislative change and surrounding controversy.
} 


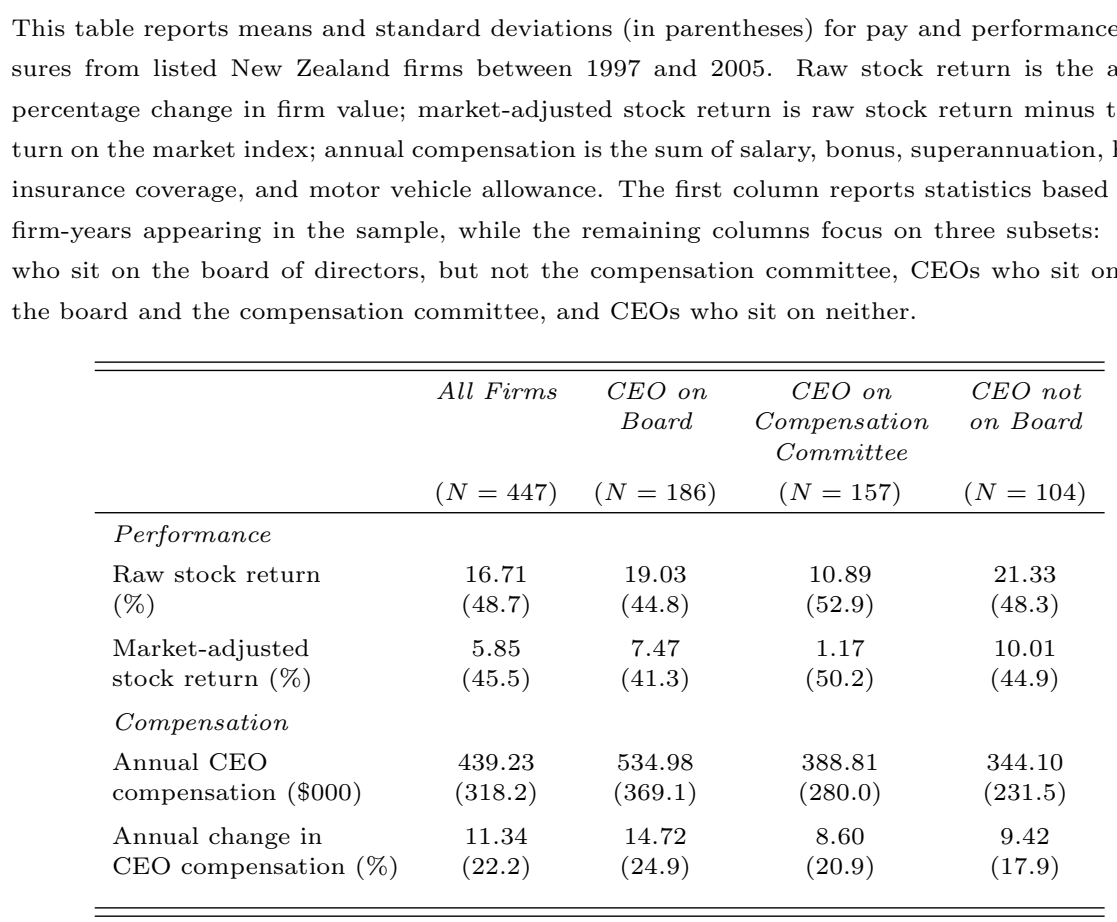

the highest payment band. ${ }^{2}$ For example, if the CEO is not a member of the board of directors and the maximum remuneration band in the annual report is $\$ 150,000-160,000$, then CEO compensation for that firm-year is estimated to be $\$ 155,000$. $^{3}$

For each firm-year, we collect performance and governance data. To proxy for performance, we use the firm's one-year market-adjusted stock return - the difference between the firm's stock return over the year and the aggregate stockmarket return (calculated using the broad-based All Ordinaries Index). ${ }^{4}$ We also record the extent of the CEO's formal involvement in the pay-setting process: a member of the compensation committee as well as the board (157 firm-years), a member of the board only (186), not a board member (104). CEOs who sit on the compensation committee might be expected to have a particularly strong influence on the compensation process, while those who are excluded from the board may be in the opposite situation.

Some summary statistics for various pay and performance variables appear in Table

\footnotetext{
${ }^{2}$ Exceptions to this rule occasionally occur when when there are identifiable employees who receive special retirement or redundancy payments that take them into the top band.

${ }^{3}$ All monetary values in this paper are expressed in NZ dollars. Inflation during the nine-year period covered by our data averaged less than $2 \%$ per annum, so the difference between real and nominal values is small. Re-estimating our models in real terms yields virtually identical results to those reported below.

${ }^{4}$ Because the relatively small and illiquid nature of NZ capital markets means that NZ firms may reward factors other than stock market performance, we also used the firm's one-year return on assets the ratio of after-tax profit to total assets - as a measure of performance. However, the results were very similar to those appearing in the following tables and changed nothing of substance, so we do not include them in the paper. They are, however, available from the authors on request.
} 
1. Across the whole sample, firms on average achieve an annual stock return of $17 \%$, while CEOs receive compensation that grows by $11.34 \%$ per annum. More interesting are the differences between the three categories of formal CEO involvement in the pay-setting process. CEOs who sit on the compensation committee receive the lowest annual growth in compensation, but the firms they lead also perform significantly less well. At the other end of the scale, CEOs who are not on the board lead the best-performing firms, but receive relatively little reward for doing so.

Although these simple statistics suggest that variation in CEO board and compensation committee involvement can influence CEO remuneration, they do not control for differences in firm performance across the three levels of involvement. This is the task to which we now turn.

\section{A puzzling result}

We regress annual CEO pay increments on firm performance and allow for different intercept coefficients corresponding to the extent of direct CEO involvement in the pay-setting process. Because NZ firms are relatively small, we estimate the pay-performance relationship in elasticity form so as to counter the observed tendency for the dollar sensitivity to decline with firm size - see, for example, Jensen and Murphy (1990), Gibbons and Murphy (1992), and Schaefer (1998). Thus, we begin by estimating the simple model: ${ }^{5}$

$$
\Delta \text { Pay }=\alpha_{0}+\alpha_{1} \mathrm{R}+\alpha_{2} D_{H}+\alpha_{3} D_{L}+\epsilon
$$

where:

$\Delta P a y=$ annual change in the natural log of CEO pay;

$R=$ annual firm performance, measured as excess stockmarket return (the

change in the natural log of (firm market value/stock market index));

$D_{H}=1$ if the CEO sits on the compensation committee and 0 otherwise;

$D_{L}=1$ if the the CEO does not sit on the board of directors and 0 otherwise.

Because some CEOs appear in the data multiple times we estimate robust standard errors that allow for clustering at the firm level. We also include a full set of time dummies (1998 being the excluded year). Our primary interest is in the estimates of $\alpha_{2}$ and $\alpha_{3}-$ the incremental effects on CEO pay growth of compensation committee membership and board exclusion respectively.

The results from estimating equation (1) appear in Column (1) of Table 2, and reveal two intriguing phenomena. First, very little of the variation in pay growth of NZ CEOs is attributable to variation in firm performance. Although statistically significant, the estimate of $\alpha_{1}$ is economically small, especially when compared to those previously

\footnotetext{
${ }^{5}$ Although unreported, we also estimate models that include lagged values of $R$ - see, for example, Hall and Liebman (1998). However, this leaves the principal results below unaffected.
} 
Table 2: CEO Influence and Pay: Basic Regressions

The dependent variable is the annual change in the natural logarithm of CEO pay. Firm performance is the annual change in the natural logarithm of firm value minus the annual change in the natural logarithm of the stock market index. Ex-officio membership of the compensation committee arises when the CEO attends committee meetings without being a member. All regressions include a full set of year dummies (1998 being the omitted year) and are based on 447 firm-year observations. Terms in parentheses are robust standard errors clustered at the firm level. ${ }^{* *}\left({ }^{* *}\right)(*)$ denotes significance at the .01 (.05) (.10) level.

\begin{tabular}{lcc}
\hline \hline Variable & $(1)$ & $(2)$ \\
\hline Intercept & $0.131^{* * *}$ & $0.134^{* * *}$ \\
& $(0.019)$ & $(0.019)$ \\
Firm performance & $0.076^{* * *}$ & $0.076^{* * *}$ \\
& $(0.029)$ & $(0.029)$ \\
CEO on Compensation Committee & $-0.039^{* *}$ & \\
& $(0.018)$ & \\
CEO not on Board of Directors & $-0.040^{* *}$ & $-0.039^{* *}$ \\
& $(0.019)$ & $(0.020)$ \\
CEO on Compensation Committee & & $-0.043^{* *}$ \\
(ex-officio) & & $(0.017)$ \\
R & & \\
F-statistic & 0.05 & 0.06 \\
\hline \hline
\end{tabular}

obtained elsewhere. For example, three representative US-based studies that estimate the elasticity form of the pay-stockmarket performance sensitivity - Murphy (1985), Hall and Liebman (1998) and Zhou (1999) - report estimates ranging from 0.16 to 0.23 , two to three times the NZ value. This suggests that NZ CEO remuneration is, on average, relatively well insulated from fluctuations in firm performance. Second, and most strikingly, the estimate of $\alpha_{2}$ is negative and statistically significant at the $5 \%$ level. Specifically, after controlling for variation in firm performance, CEO membership of the compensation committee is associated with annual pay growth that is approximately four percentage points lower than that enjoyed by CEOs who sit only on the board. Just as surprisingly, this 'penalty' is almost identical to that associated with not being on the board at all $\left(\alpha_{3}\right)$. Quantitatively, the $\mathrm{CEO}$ of the average-performing firm in our sample receives an annual pay increment of $13.5 \%$ if he has board membership, but this falls to $9.5 \%$ if he isn't a board member, or to $9.6 \%$ if he is a board member who also sits on the compensation committee - a monetary difference of just under $\$ 20,000 .{ }^{6}$

One possible objection to this puzzling finding is that some CEOs may exert influence over the compensation committee even when they are not members, resulting in a misclassification of those CEOs. If these CEOs are highly paid, then our estimate of the

\footnotetext{
${ }^{6}$ From Table 1 , the average firm-year performance is $5.85 \%$, so the estimated pay growth from column (1) of Table 2 is $0.131+0.076^{*} 0.0585=0.135$ if the CEO is on the board but not the compensation committee, and $0.131+0.076^{*} 0.0585-0.039=0.096$ if on the compensation committee as well.
} 
'penalty' for compensation committee membership is overstated. To address this potential problem, we search company annual reports for evidence of 'ex-officio' CEO membership of the compensation committee. This typically shows up in the form of a footnote statement along the following lines: "while (CEO name) is not a member of the compensation committee, he attended these committee meetings in his capacity as CEO". For every firm-year where this occurs, we re-classify it as a CEO who has compensation committee membership, resulting in 19 additional observations in that category (with 11 and 8 respectively fewer in the board-only and not-on-board categories). We re-estimate equation (1) using this alternative measure of compensation committee membership and report the results in column (2) of Table 2. However, this only exacerbates the puzzle - the compensation committee penalty is now slightly larger and is more precisely estimated.

\section{How robust is the puzzle?}

The result that compensation committee membership is associated with less generous CEO pay increases is surprising and counter-intuitive. In this section, we consider some obvious explanations for this puzzle.

\subsection{Omitted governance variables}

One possibility is that our CEO board-involvement categorization is inadvertently picking up other more fundamental governance features, thus resulting in a spurious relationship between pay increases and compensation committee membership. To investigate this possibility, we employ three governance variables identified by Core et al. (1999) as being potentially important determinants of CEO pay - board size (the number of directors), independent director representation (the proportion of directors who are independent), and CEO-Chair duality. ${ }^{7}$ We re-estimate equation (1) including these three variables and report the results in column (1) of Table 3. Although greater board size is weakly associated with higher pay growth, the inclusion of the governance variables has no effect on our estimate of $\alpha_{2}-$ CEO membership of the compensation committee remains associated with annual pay growth that is approximately four percentage points lower than that enjoyed by other CEOs. If anything, the puzzle is exacerbated by the inclusion of the governance variables since the $\alpha_{3}$ estimate is now statistically indistinguishable from zero, implying that CEOs who sit on the compensation committee are rewarded less generously even than those who are excluded from the board altogether.

\footnotetext{
${ }^{7}$ See Core et al. (1999) for a discussion of the economic link between these variables and CEO pay. Boyle and Ji (2011) provide some historical summary statistics for these variables in NZ firms over the period covered by our data.
} 
Table 3: CEO Influence and Pay: Governance, Risk and Selection The dependent variable is the annual change in the natural logarithm of CEO pay. Board Size is the number of directors on the board; Independent Directors is the proportion of directors who are independent; CEO-Chair $=1$ if the CEO is also the board chair and 0 otherwise. Column (3) is the second stage of a two stage procedure in which the first stage accounts for possible selection effects in the board role of the CEO: Lambda is the selection parameter for CEO compensation committee membership and Gamma is the selection parameter for CEOs who are not members of the board. All regressions include a full set of year dummies (1998 being the omitted year) and are based on 447 observations. Terms in parentheses are robust standard errors clustered at the firm level. ${ }^{* * *}\left({ }^{* *}\right)\left({ }^{*}\right)$ denotes significance at the .01 (.05) (.10) level.

\begin{tabular}{|c|c|c|c|}
\hline & (1) & (2) & (3) \\
\hline Intercept & $\begin{array}{c}0.196^{* * *} \\
(0.080)\end{array}$ & $\begin{array}{c}0.131^{* * *} \\
(0.019)\end{array}$ & $\begin{array}{c}0.234^{* * *} \\
(0.061)\end{array}$ \\
\hline Firm performance & $\begin{array}{c}0.080^{* * *} \\
(0.026)\end{array}$ & $\begin{array}{c}0.122^{* * *} \\
(0.033)\end{array}$ & $\begin{array}{c}0.061^{* *} \\
(0.031)\end{array}$ \\
\hline CEO on Compensation Committee & $\begin{array}{c}-0.039^{* *} \\
(0.018)\end{array}$ & $\begin{array}{c}-0.042^{* *} \\
(0.017)\end{array}$ & $\begin{array}{c}-0.232^{* *} \\
(0.104)\end{array}$ \\
\hline CEO not on Board of Directors & $\begin{array}{c}0.001 \\
(0.034)\end{array}$ & $\begin{array}{c}-0.040^{* *} \\
(0.019)\end{array}$ & $\begin{array}{l}-0.204 \\
(0.144)\end{array}$ \\
\hline Board Size & $\begin{array}{l}0.009^{*} \\
(0.005)\end{array}$ & & \\
\hline CEO-Chair & $\begin{array}{c}0.022 \\
(0.037)\end{array}$ & & \\
\hline Independent Directors & $\begin{array}{l}-0.164 \\
(0.013)\end{array}$ & & \\
\hline $\begin{array}{l}\text { Firm performance } * \text { CEO } \\
\text { on Compensation Committee }\end{array}$ & & $\begin{array}{l}-0.074 \\
(0.062))\end{array}$ & \\
\hline $\begin{array}{l}\text { Firm performance } * \text { CEO } \\
\text { not on Board }\end{array}$ & & $\begin{array}{l}-0.057 \\
(0.065)\end{array}$ & \\
\hline Lambda & & & $\begin{array}{l}0.121^{*} \\
(0.065)\end{array}$ \\
\hline Gamma & & & $\begin{array}{c}0.099 \\
(0.088)\end{array}$ \\
\hline $\mathrm{R}^{2}$ & 0.07 & 0.06 & 0.06 \\
\hline F-statistic & $2.42^{* * *}$ & $2.30^{* * *}$ & $2.36^{* * *}$ \\
\hline
\end{tabular}

\subsection{Risk-return tradeoff}

Another possible explanation for the puzzle is that the lower pay growth associated with CEO membership of the compensation committee reflects a risk-return tradeoff by riskaverse CEOs. Specifically, CEOs who sit on the compensation committee may use their 'power' to negotiate a low-risk, low-return remuneration package. According to this story, the negative estimate of $\alpha_{2}$ is simply the price risk-averse CEOs pay in order to reduce their compensation risk.

To test this story, we re-estimate equation (1) including two additional variables 
that interact firm performance with $D_{H}$ and $D_{L}$ respectively. However, as can be seen in column (2) of Table 3, neither interaction variable is even close to being statistically significant, while the estimate of $\alpha_{2}$ actually rises slightly. The puzzle does not, therefore, appear to be the result of risk-return considerations by risk-averse CEOs.

\subsection{Selection}

A third possibility is that the 'selection' of CEOs who sit on the compensation committee is not random. For example, CEOs who expect their future pay growth to be constrained - for whatever reason - may actively seek compensation committee membership in order to best minimize the pain. According to this view, the negative estimate of $\alpha_{2}$ reflects self-selection by CEOs (and/or the firms that employ them).

To investigate this idea, we employ the Campa and Kedia (2002) implementation of the two-stage Heckman (1979) procedure. The first stage estimates probit models of the decisions to (i) include the CEO on the compensation committee and (ii) to exclude the CEO from the board. The results of these models are used to estimate selection parameters (corresponding to each of the two decisions) which are then included as additional explanatory variables in equation $(1) .^{8}$

The results of this exercise appear in column (3) of Table 3. Allowing for selection makes the puzzle worse: the coefficient on the compensation committee selection variable is positive rather than negative, suggesting that firm characteristics which encourage CEO membership of the compensation committee also tend to encourage high pay growth. As a result, the estimate of $\alpha_{2}$ becomes even more negative. ${ }^{9}$

\subsection{Cash versus total compensation}

Finally, we consider the possibility that our results are at least partly an artifact of our focus on cash, as opposed to total, compensation. It could be, for example, that CEOs who sit on the compensation committee are giving up some cash remuneration in exchange for stock options of greater value. In this case, compensation committee membership would indeed be associated with lower cash remuneration, but there would be no puzzle.

As discussed in section 2, we are unable to test this idea directly by using total compensation growth as an alternative dependent variable in equation (1). However, we can get some idea of its plausibility by comparing the frequency of option awards across the three CEO 'involvement' categories. Such a comparison turns out to be revealing: of the 51 option grants made during our sample period, 13 are to CEOs who serve on the compensation committee, 36 are to CEOs who sit on the board only, and 2 are to non-

\footnotetext{
${ }^{8}$ The explanatory variables used in the first-stage probit models are firm performance, firm sales, and firm risk - as measured by the standard deviation of monthly firm stock returns for the five-year period ending the last day of the previous fiscal year.

${ }^{9}$ We also estimate models that include combinations of the variables introduced in the various columns of Table 3, but this has no effect on the puzzle.
} 
board CEOs. Relative to the total numbers of observations (see Table 1), these correspond to $8.3 \%, 19.3 \%$ and $1.9 \%$ respectively of firm-years in the three categories. Given that CEOs who are not members of the compensation committee receive option grants at more than twice the rate of CEOs who are members, it seems unlikely that our focus on cash compensation is responsible for the puzzle.

\section{Concluding Remarks}

Much has been written about executive compensation, but surprisingly little is known about how this is affected by formal CEO involvement in the executive pay-setting process. At one extreme, CEO membership of the rms compensation committee would seem to represent a significant departure from the arms-length bargaining model envisaged by agency theory, and hence create the potential for opportunistic CEO behaviour. At the other, CEOs who are not part of the board of directors would appear to be in a relatively weak bargaining position when it comes to negotiating their personal remuneration. We examine this issue using data from New Zealand, where there exists considerable variation in the extent of formal $\mathrm{CEO}$ involvement. After controlling for variation in firm performance, we find, surprisingly, that annual pay increments for CEOs with compensation committee membership averaged four percentage points less than those enjoyed by other CEOs during the 1997-2005 period. Moreover, this unexpected outcome cannot be explained by some obvious candidates - risk-return tradeoff considerations, interaction with other governance variables, selection bias, or variable mis-measurement - and so represents something of a puzzle.

Although the last decade, in particular, has seen a significant number of welldocumented cases of seemingly-excessive CEO compensation, the evidence in this paper indicates that, at least in NZ, such cases are unlikely to arise as the result of CEO membership of the compensation committee. If anything, our results suggest that highly-visible arrangements which, on the surface, appear an open invitation for CEOs to behave opportunistically, may in fact induce them to exercise greater restraint. 


\section{References}

Anderson, Ronald C. and John M. Bizjak, 2003, An empirical examination of the role of the CEO and the compensation committee in structuring executive pay, Journal of Banking and Finance 27, 1323-1348.

Andjelkovic, Aleksandar, Glenn Boyle, and Warren McNoe, 2002, Public disclosure of executive compensation: Do shareholders need to know? Pacific-Basin Finance Journal $10,97-117$.

Boyle, Glenn and Xu Ji, 2011. New Zealand corporate boards in transition: composition, activity and incentives between 1995 and 2010. University of Canterbury working paper.

Campa, José and Simi Kedia, 2002. Explaining the diversification discount. Journal of Finance 57, 1731-1762.

Core, John E., Robert W. Holthausen, and David F. Larcker, 1999. Corporate governance, chief executive officer compensation, and firm performance. Journal of Financial Economics 51, 371-406.

Gibbons, Robert, and Kevin J. Murphy, 1992, Optimal incentive contracts in the presence of career concerns: theory and evidence, Journal of Political Economy 100, 468-505.

Hall, Brian J., and Jeffrey B. Liebman, 1998, Are CEOs really paid like bureaucrats?, Quarterly Journal of Economics 113, 653-691.

Heckman, James, 1979, Sample selection bias as a specification error, Econometrica 47, $153-61$.

Jensen, Michael C. and Kevin J. Murphy, 1990, Performance pay and top-management incentives, Journal of Political Economy 98, 225-264.

Klein, April, 1998, Firm performance and board committee structure, Journal of Law and Economics 41, 275-303.

Leblanc, Richard and James Gillies, 2005. Inside the Boardroom: How Boards Really Work and the Coming Revolution in Corporate Governance. Wiley, Canada.

Murphy, Kevin J., 1985, Corporate performance and managerial remuneration, Journal of Accounting and Economics 7, 11-42.

Newman, Harry A., and Haim A. Mozes, 1999, Does the composition of the compensation committee influence CEO compensation practices? Financial Management 28, 41-53.

Schaefer, Scott, 1998, The dependence of pay-performance sensitivity on the size of the firm, Review of Economics \& Statistics 80, 436-443. 
Vafeas, Nikos, 2003, Further evidence on compensation committee composition as a determinant of CEO compensation, Financial Management 32, 53-70.

Zhou, Xianming, 1999, Executive compensation and managerial incentives: a comparison between Canada and the United States, Journal of Corporate Finance 5, 277-301. 